\title{
Sinkó, Ervin. 2018. The Novel of a Novel, Abridged Diary Entries from Moscow, 1935-1937. Ed. and Trans. George Deák. London, Boulder and New York: Lexington Books. 343 pp.
}

\author{
Reviewed by Veronika Schandl ${ }^{1}$, Pázmány Péter Catholic University
}

Ervin Sinkó's name sounds unfamiliar even to Hungarian readers. Although a prolific writer, a member of the mythic Nyugat magazine generation, the founder and director of the Hungarian department of Novi Sad University, his works have only been recently discovered by Hungarian literary critics. The reasons for Sinkó's relative obscurity are manifold, but the fact that his works are hard to fit into clear-cut categories is definitely part of the problem. The publication of his book The Novel of a Novel [A regény regénye, 1953] in English might therefore serve as a great opportunity to provide Sinkó with a larger audience that can appreciate his oeuvre.

Sinkó's works are inseparable from the vicissitudes of his life. Born in 1898 to a Hungarian-Jewish family in Apatin (in Vojvodina, Serbia, at that time Vajdaság, Hungary), he experienced marginalization from an early age, as seen already in his early poetry, which deals much with existential loneliness and alienation. His sympathies from early childhood with the oppressed and voiceless later led him to the Social-Democratic Party and the literary circles of Lajos Kassák. After serving on the Russian front in the First World War he became disillusioned in the Western world, left Kassák's circle and became a founding member of the Hungarian Communist Party. During the one hundred and thirty three days of the Hungarian Soviet Republic of 1919 Sinkó took several official positions, among them that of the city commander of Kecskemét (a medium-sized town in Eastern Hungary), where he had a chance to practice his humanist ideals (on at least two occasions he saved members of the Hungarian militia from being convicted on political ground and, instead, ordered that they attend reeducation classes). During the final days of the Commune he fought on the Romanian front, then sought exile in Vienna, Sarajevo, Graz and finally Paris. In 1928, while active in Hungarian literary circles living in exile, he started writing his novel Optimists, a work that expresses his intellectual crisis as well as his Tolstoyan Neo-Christianism. The novel discusses the events of the Hungarian Soviet Republic through a personal fictionalized point-of-view. It is neither a history book nor an apologia for the Hungarian Communist Party, and ultimately it is a novel that no one wanted to publish - neither the Party, nor any dissident literary circles. This, then, is the moment in Sinkó's life where his Novel of A Novel starts.

${ }^{1}$ schandl.veronika@btk.ppke.hu

(cc) BY

ULLS D-Serbe
New articles in this journal are licensed under a Creative Commons Attribution 4.0 International License.

This journal is published by the University Library System of the University of Pittsburgh as part of its D-Scribe Digital Publishing Program and is cosponsored by the University of Pittsburgh Press 
Schandl, Veronika. "Sinkó, Ervin. 2018. The Novel of a Novel, Abridged Diary Entries from Moscow, 1935-1937. Ed. and Trans. George Deák. London, Boulder and New York: Lexington Books. 343 pp." Hungarian Cultural Studies. e-Journal of the American Hungarian Educators Association, Volume 12 (2019) DOI:

The novel of a Novel opens with our hero, the writer expressing himself in the first person, in Paris, jobless and hopeless, trying to find a publisher for his grand opus. Somewhat like in a picaresque novel, this mission launches Sinkó's quest, as well as connects the events that unfold later on. While seemingly out of luck in Paris, he eventually gets an opportunity, through novelist Romain Rolland, to travel to the USSR in 1935 with the hope that the cultural setting there might be more auspicious toward his novel. In fact, the main part of The Novel of a Novel deals with Sinkó's 1935-1937 journey to the Soviet Union, detailing the adventures that both he and the manuscript have in Moscow, but also describing Sinkó's gradual realization of how the cultural politics of Stalin's regime actually work.

As the title suggests, the novel is a palimpsest of several layers. Its backbone is Sinkó's diary from his stay in the USSR, revised in 1953 by Sinkó himself. Keeping a diary in the Soviet Union was brave - and somewhat foolhardy - in itself, as a Hungarian Communist in Moscow also remarks to Sinkó. The real impudence of its author came, however, when leaving Moscow in 1937 Sinkó simply mailed the diary to his Paris address, so it was not searched, let alone confiscated by the Secret Police as were all his other manuscripts that he took with himself. In addition to the diary are comments the author added to it later on. An advantage of the English rendition over the original Hungarian text is that it helps the reader differentiate between these two layers, with the later commentary appearing in italics. The comment section is an interesting read in itself, since it sometimes offers viewpoints that are strikingly different from those of the diary. This divergence is a fundamental characteristic of Sinkó's oeuvre, and it turns his novel into an exhilarating journey into the psyche of an inquisitive, thinking man, for whom " $[\mathrm{t}] \mathrm{here}$ is no feeling more chokingly oppressive than the suspicion that perhaps, after all, your whole way of life, its content, the very essence of your life is built on a false premise" (7). It is no surprise, then, that Sinkó always questions his preconceptions: he wavers from Communism to Christianism (notwithstanding his Jewish roots), from internationalism to a constant acknowledgment of his Hungarianness, and from feeling an outsider to whichever frame to a heartfelt wish to belong.

The Novel of a Novel offers itself to several readings. It can be understood as a telling historical document, a contemporary account filled with famous people responding to the growing terror in Stalinist Russia (from Count Michael Károlyi to Béla Kun, through József Révai and Andor Gábor, Sinkó met everyone in the Hungarian exile circles, as well as several well-known members of the Soviet cultural scene, from Eizenstein to Isaak Babel through Dimitrov). It could also be read as an account of a personal journey, an introspection and a confession, the mental evolution of a man full of good intentions and thus reluctant to fully acknowledge his life's circumstances. The novel, including its vital, engaging style, was recently translated by George Deák into flowing, rich English, so that whichever aspect the reader is interested in, be it a thrilling expedition into the darkest circles of State Socialism, or a memoir of a man torn between his beliefs and the reality he experiences, is readily accessible through Deak's competent translation.

What then is The Novel of a Novel really about? It relates Sinkó's heroic ascent from rags to riches, then back to rags and up again in the Soviet Union, where he arrives with support from the Komintern, gets a luxurious welcome in the prime hotels of Moscow, while his novel is being translated into several languages. Once, however, the full content of Optimists becomes clear to the authorities, he again falls from grace and now has to reside in bug-infested apartments in the Klubnaja district of Moscow. By this time, officials hiding behind desks avoid meeting him, all 
Schandl, Veronika. "Sinkó, Ervin. 2018. The Novel of a Novel, Abridged Diary Entries from Moscow, 1935-1937. Ed. and Trans. George Deák. London, Boulder and New York: Lexington Books. 343 pp." Hungarian Cultural Studies. e-Journal of the American Hungarian Educators Association, Volume 12 (2019) DOI:

in the effort to eschew acknowledging that the regime made a mistake, because in the era of the USSR cultural wars of the mid-1930s Sinkó's novel is unacceptable. Then, thanks to a lucky twist of fate, Sinkó gets to share an apartment with Isaac Babel, who assists him in various ways. Yet, when his contract with the Film Fund is cancelled, Sinkó sues the Fund, an act that estranges him from Babel and eventually results in him having to flee Moscow and return to Paris. Once in the French capital, he receives the message that if only he writes a glorifying account of the Soviet regime's show trials, then his novel would, after all, be published. Sinkó refuses, claiming that he has never written anything he did not believe in, yet at the same time he also warns others against openly publishing overly critical accounts of the Soviet Union, since, so he insists, that would only bolster Nazi propaganda.

The novel's main forte lies in the myriad anecdotes introducing to us the stratified world of Parisian refugees, the morally questionable status of Hungarian exiles who played an instrumental part in the Commune, and - most importantly - the everyday life of Moscow in 1935, all against the backdrop of Stalinist cultural politics. Naturally, all this is brought to us through Sinkó's lens, his personal filter that in retrospect often seems naïve. Whenever he is taken aback because his comments on Nietzsche's brilliance are criticized, or when he fails to notice the double standards practiced by his contemporaries, the reader has to wince at his innocence. Alternatively, seen through the prism of time, one could replace naivety with selfirony. This reading is supported by the way in which the incidents are woven into each other all within a highly self-reflective narrative in which Sinkó contemplates on the overall state of the Soviet people. He frequently criticizes Soviet culture, with its strict adherence to SocialistRealist rules and to a standard of middlebrow operettas and formalist paintings. He also slowly recognizes the growing fear and instability in the everyday life of Soviet citizens, as well as the increasing division between public and private discourse.

The only incident when Sinkó's personal grievance incapacitates him from understanding how one would act in an authoritarian society is when Babel, mostly to save his own existence, fails to support him in his court case, a cause doomed to fail anyway. For Sinkó, Babel's abandonment signals the demise of honesty and decency, ideas and values that are essential to Sinkó's conduct in life and which he deems worthily European. It is because of his ultimate adherence to principles that, despite all the horrors he experiences and all the conclusions he draws (or does not) from them, the novel ends with the admittance that if to defeat the Nazis the price to pay is the living Socialism of the Soviet Union, then it is a price worth paying. To back this claim the novel ends with Paris at the brink of the Second World War and the danger of the German army occupying France becoming imminent.

In the postscripts to the novel Sinkó delineates the fates of several characters who appear in the course of the book, and he concludes with a discussion that ultimately warns against all ideologies since "[t]here is no ideology and no social system that automatically liberates man" (354). The novel in itself, however, does not end on such an unequivocal declaration. Rather, it is a lesson on the moral traps that a thinking individual can fall into. All this makes Ervin Sinkó's The Novel of Novel a thought-provoking journey into the psyche of a man, who, through all his self-questioning struggles, provides us with an invaluable insight into the "how"s and "why"s of twentieth-century history. It is a novel that more people around the world should read, and George Deák's fine English translation might help it accomplish this goal. 